\title{
NEWS
}

\section{Europe moves to secure its future energy supply}

A sweeping proposal for a common energy policy for Europe, unveiled last week by the European Commission, calls for a radical shift towards a low-carbon economy. Although environmental campaigners have criticized the proposal for not going far enough, other experts say that the plan is much more ambitious and concrete than any suggested before.

The commission recommends a combination of regulatory and technological measures to secure the future energy supply of the European Union (EU) and to reduce the risk of dangerous climate change. It says that the package would help to cut the EU's greenhouse-gas emissions by at least $20 \%$ (compared with 1990 levels) by 2020 .

The commission suggests that renewable energy sources in the EU should make up $20 \%$ of the overall energy mix by 2020. Energy generated from wind, solar and other renewable sources currently account for less than $7 \%$ of total energy consumption. The commission also calls for biofuels to provide at least $10 \%$ of the energy used by the transport sector by 2020.

Imported fossil fuels are projected to remain the main source of energy, however, and the proposed policy includes a commitment to equip the next generation of coal-fired power plants with the technology to capture and store carbon dioxide, which would enable them to operate with low or zero greenhouse-gas emissions. It is the first time that the use of such technology has been proposed at such a high political level.

The report will be discussed by the EU's heads of state at a summit meeting in March. If approved, the recommendations must be translated into national law in all 27 member states.

Policy analysts doubt that all the proposed actions and targets will be accepted. But given the vagueness of previous reviews, experts say that they appreciate the concreteness and level of detail of the proposed changes.

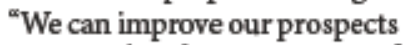
for energy security and carbon emissions if these recommendations are followed through, even though it will be difficult to get agreement on all of them," says John Mitchell, an associate fellow with the energy environment and development programme at London-based Chatham House.

And the energy industry, although critical about some of the details, has welcomed the main thrust of the report. "We do know that our fossil future is limited," says a spokeswoman for

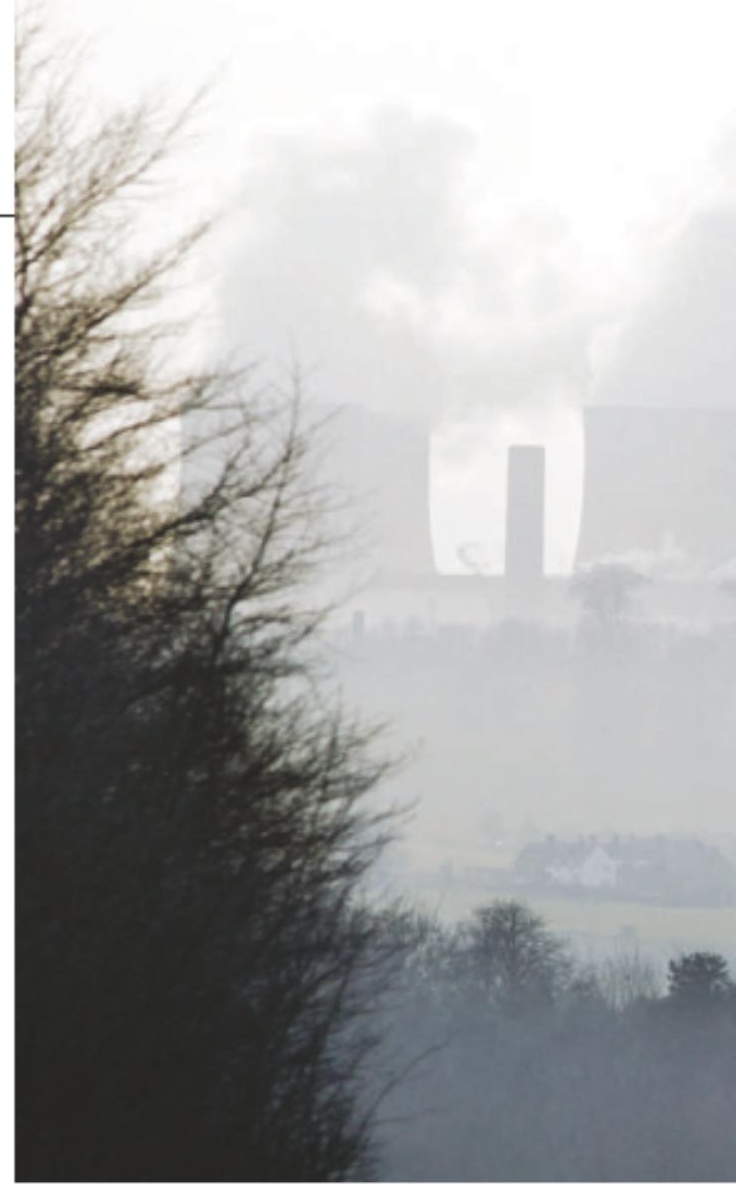

the Germany energy company RWE.

The most controversial part of the proposal may be the call for a single energy market within the EU. The report calls for trade barriers to be lifted and for the production of energy to be separated from its distribution, to increase competition and allow citizens to choose to buy 'green' energy if they want to as well as reducing dependence on any one source of energy. In the past, energy companies in Germany and France have blocked such moves, and they are expected to keep up their resistance.

\section{Palaeontology journal will 'fuel black market'}

Acontroversial new 'amateur' palaeontology journal has angered academic researchers, who fear that the project will give a sheen of scientific legitimacy to the dealings of commercial fossil hunters.

The organizers of the Journal of PaleontologicalSciences, launched this month, say that it will publish details of privately held fossils, bringing them in from the "scientific darkness". But traditional palaeontologists say that the journal undermines the fieldand couldfuel the black market in fossil specimens.

The journal is inviting anyone, including commercial fossil hunters and keen amateur collectors, to publish details of their finds. "Lurking in many private collections are valuable fossil treasures. This is the first journal that gives anoutlet to the amateur and commercial palaeontologist to try their hand at writing a scientific article," says Ken Carpenter, a member of the journal's publication committee and curator of vertebrate palaeontology at the Denver Museum of Nature and Science in Colorado.

But academics are upset that the fossils will not be in the public domain, and will therefore be unavailable for future study. "This is absolutely imperative in order for our science to exist," says Mark Goodwin at the University of California

Museum of Paleontology in Berkeley.

Palaeontologists who publish their results in traditional journals, such as the Journal of Vertebrate Paleontology, agree to abide by a code of ethics, whereby they catalogue their specimens in a recognized repository, most often a nationalmuseum. Good win thinks that the new journal is an attempt to circumvent this practice.

The fears are fuelled by the fact that many of the fossils that change handsin commercial deals do so on the black market. "Promotion of this online journal will encourage the commercialization of vertebrate palaeontology, which unfortunately results in increased illegal collecting activities on public lands in the United States, and the illegal trade and export of fossils from China, other regions of Asia, and the former Soviet Union," Goodwin argues.

Walter Stein, chair of the journal's public ation committee and president of PaleoAdventures in Belle Fourche, South Dakota, disagrees. He thinks that some exposure for the privately held 
